\title{
Magdalena DaneK
}

Uniwersytet Jagielloński

\section{KOBIETY JAKO KOMENTATORKI \\ ŻYCIA PUBLICZNEGO W POLSKICH PROGRAMACH PUBLICYSTYCZNYCH}

\section{Wstęp}

Kwestia nierówności w dostępie kobiet do wyższych stanowisk w Polsce, jak również w rozwoju kariery zawodowej, jest przedmiotem licznych badań i dyskusji. Paradoksalnie samo środowisko badaczy nie jest wolne od tego typu dysproporcji. Swoją refleksję na ten temat na łamach pisma „Forum Akademickie” przedstawiła dr Agnieszka Pawłowska-Kubik, pisząc:

[...] dopóki w nauce będzie panowała męska solidarność, zmaskulinizowany punkt widzenia świata i rodziny, dopóty kobiet w nauce będzie za mało. [...] Postawa osób, które powinny być żywo zainteresowane wzrostem partycypacji kobiet w nauce polskiej, zamyka się na niewiedzy i życzeniowości. [...] Może w takim razie, drogie panie, rzeczywiście lepiej skupić się na rodzeniu dzieci i, jak to pięknie się mówi, „dbaniu o domowe ognisko"? A w przerwie od mieszania zupy i zmieniania pieluch przeczytać o ubolewaniu mężczyzn nad brakiem kobiet w polskiej nauce ${ }^{1}$.

\footnotetext{
${ }^{1}$ A. Pawłowska-Kubik, Kilka gorzkich refleksji, „Forum Akademickie” 2016, 9,
} s. 23 . 
Ta smutna konstatacja pokazuje, że mimo dużych zmian, jakie już nastąpiły w społecznej świadomości, problem nierównych szans kobiet i mężczyzn nadal jest mocno widoczny. Także w świecie polityki i mediów, co będzie głównym przedmiotem tego artykułu.

Badania wskazują na stopniowe zwiększanie się liczby kobiet jako czynnie zaangażowanych polityków. Niebagatelną rolę odegrały w tym zakresie zmiany w kodeksie wyborczym, które narzucają układanie list wyborczych z zachowaniem odpowiedniej proporcji reprezentantów odmiennych płci. Jak pokazały wybory parlamentarne w Polsce w 2011 i 2015 roku, kwoty na listach rzeczywiście wpłynęły na wzrost liczby kobiet wybranych do Sejmu RP. Nie był to jednak efekt spektakularny. Pomiędzy kolejnymi kadencjami liczba kobiet zwiększała się o 3\%. Warto więc zastanowić się nad innymi czynnikami, które mogą mieć wpływ na nadal niewielką obecność kobiet w polskim życiu politycznym.

W dobie, kiedy komunikacja społeczna, w tym komunikowanie polityczne, jest silnie powiązana ze środkami masowego komunikowania, warto zwrócić uwagę na istotne znaczenie mediów w tym zakresie. Poprzez częstotliwość zapraszania kobiet polityków do programów, w których na bieżąco są komentowane ważne sprawy z życia publicznego, media wpływają pośrednio na kształtowanie społecznej świadomości odnośnie do płci sfery politycznej. Rzadsza słyszalność głosu kobiet w tego typu programach wpływa na przekonanie odbiorców, że sfera publiczna to obszar, który naturalnie jest zarezerwowany bardziej dla męskiego punktu widzenia. Dla lepszego zobrazowania tej kwestii na potrzeby niniejszego artykułu została przeprowadzona ilościowa analiza treści programów publicystycznych emitowanych po głównych wydaniach serwisów informacyjnych stacji: TVP Info, TVN24 i Polsat News.

Kobiety w parlamencie - mały krok w dobrym kierunku

Aktywny udział kobiet w życiu politycznym zarówno w Polsce, jak i w innych zakątkach świata wykazuje w ostatnich latach systematyczną 
tendencję wzrostową. Według danych Unii Międzyparlamentarnej (Inter-Parliamentary Union), 1 grudnia 2016 roku kobiety stanowiły ok. 23\% wszystkich parlamentarzystów. W porównaniu do stanu z 31 grudnia 2010 roku jest to wzrost o 4 punkty procentowe, a w stosunku do 31 grudnia 2005 roku udział kobiet w światowych parlamentach zwiększył się o blisko $9 \% 2$.

Zwiększanie się liczby kobiet w życiu politycznym widać również w polskim Sejmie. Należy jednak zaznaczyć, że trend ten charakteryzuje się raczej powolnym wzrostem. Obecnie w niższej izbie polskiego parlamentu zasiada $27 \%$ kobiet. Jest to rekordowy wynik w porównaniu z poprzednimi kadencjami (w stosunku do ostatniej nastąpił wzrost o 3 punkty procentowe). Na tym tle gorzej wypada obecność kobiet w polskim Senacie, która w stosunku do poprzedniej kadencji pozostała na niskim poziomie 13\%. Jak wskazuje analiza Instytutu Spraw Publicznych, jest to efekt działania jednomandatowych okręgów wyborczych, które w przeciwieństwie do wprowadzonej w 2011 roku tzw. ustawy kwotowej premiują męskich liderów. W konsekwencji kobiety w wyborach do Senatu stanowiły jedynie 14\%. Co więcej, aż w 57\% okręgów wyborczych nie została zarejestrowana żadna kandydatka. Dla porównania tylko w jednym okręgu, a dokładnie w okręgu rzeszowskim, nie wystawiono żadnego mężczyzny³.

W odniesieniu do wyborów do Sejmu RP w 2015 roku warto ponadto zauważyć, że niektóre partie polityczne wprowadziły dodatkowe regulacje stanowiące uzupełnienie systemu kwotowego. Partia Nowoczesna promowała udział kobiet poprzez wprowadzenie zasady, że na każdej liście musi być co najmniej jedna kobieta w pierwszej trójce (zasada nie została zachowana tylko na czterech listach). Platforma Obywatelska RP układała swoje listy według reguły: jedna kobieta w pierwszej trójce, dwie w pierwszej

${ }^{2}$ www.ipu.org/wmn-e/world.html (3.01.2017).

${ }^{3}$ A. Chełstowska, M. Druciarek, A. Niżyńska, N. Skoczylas, Udział kobiet $w$ wyborach parlamentarnych $w 2015$ roku. Wyniki monitoringu Obserwatorium Równości Płci, Warszawa 2015, https://pl.boell.org/sites/default/files/udzial_kobiet_wybory_parlamentare_2015_isp_hbs.pdf (3.01.2017). 
piątce (wyjątkiem były tylko trzy okręgi wyborcze). To wzmocnienie wprowadzonego ustawą systemu kwotowego przyniosło konkretny efekt. Partia Ryszarda Petru wprowadziła do Sejmu najwięcej kobiet wśród swoich reprezentantów, bo aż 43\%. Na drugim miejscu znalazła się Platforma Obywatelska RP z wynikiem 36\%. Dla porównania procentowy udział kobiet wybranych z ramienia innych partii do Sejmu RP wynosi dla PiS - 23\%, PSL - 19\%, Kukiz'15 - 14\% ${ }^{4}$. To pokazuje, że zastosowanie samych kwot nie przynosi spektakularnych efektów.

W związku z tym nasuwa się zasadnicze pytanie, czy odgórne regulacje w kodeksie wyborczym są wystarczającymi działaniami, które doprowadzą do systematycznego zwiększania się liczby polityków płci żeńskiej. Tendencja w tym zakresie jest wzrostowa, jednak charakteryzuje się słabą dynamiką. Niewątpliwie należy zwrócić uwagę na pozostałe aspekty, które odgrywają niebagatelną rolę w tym procesie.

Profesor Małgorzata Fuszara, jedna z najbardziej znanych polskich badaczek przemian ról społecznych kobiet i mężczyzn, wskazuje, że oprócz środków prawnych ważną rolę odgrywa stan świadomości społecznej. $\mathrm{W}$ tym aspekcie istotny jest preferowany model rodziny (tradycyjny, partnerski, mieszany bądź odwrócony) oraz pogląd na piastowanie przez kobiety stanowisk $\mathrm{w}$ życiu publicznym i politycznym ${ }^{5}$. Jak pokazują badania CBOS, w ostatnich latach w tych kwestiach nastąpiła znacząca zmiana. Wśród Polaków rośnie przekonanie, że równy podział obowiązków domowych i solidarny udział kobiet i mężczyzn w pracy zawodowej jest najlepszą opcją. W 2012 roku 48\% Polaków za pożądany model rodziny określiło model partnerski (partnerzy w równym stopniu realizują się zawodowo i dzielą między siebie obowiązki związane z prowadzeniem gospodarstwa domowego oraz opieką nad potomstwem), 27\% popierało model mieszany (zarówno kobieta, jak i mężczyzna pracują, ale to na kobiecie w głównej mierze spoczywa ciężar domowych obowiązków), 22\% obstawało przy

${ }^{4}$ Ibidem.

${ }^{5}$ M. Fuszara, Kobiety w polityce, Warszawa 2006, s. 11-32. 
modelu tradycyjnym (tylko mężczyzna podejmuje pracę zawodową, kobieta zaś poświęca czas obowiązkom domowym), a tylko $1 \%$ opowiedział się za modelem odwróconym (kobieta pracuje i utrzymuje rodzinę, natomiast partner przejmuje obowiązki domowe) ${ }^{6}$. Dla porównania według badań prof. Fuszary jeszcze w 1994 roku za trakcyjnym modelem rodziny opowiadało się 42\%, a za partnerskim 35\% Polaków.

Na kształtowanie świadomości społecznej istotny wpływ wywierają stereotypy. Szczególnie istotne przy omawianiu niniejszej tematyki jest zjawisko stereotypizacji społeczno-kulturowej uwarunkowanej płcią ${ }^{7}$. W tym miejscu warto odnieść się do terminu płci kulturowej, który według Anthony’ego Giddensa można zdefiniować jako „oczekiwania dotyczące cech społecznych, kulturowych i psychologicznych oraz sposobów zachowania uważanych za właściwe dla członków danego społeczeństwa”». Jak dalej wskazuje Giddens, za tworzenie się różnic pomiędzy płciami kulturowymi odpowiada socjalizacja płciowa, która dokonuje się za pomocą działania takich instytucji społecznych, jak rodzina, szkoła czy media 9 .

W dzisiejszym społeczeństwie, w którym zarządzanie informacją odgrywa niezwykle istotną rolę, to właśnie media mogą wywierać znaczący wpływ na udział kobiet w życiu publicznym i politycznym. Media są nie tylko przekaźnikami informacji i źródłami rozrywki, ale przede wszystkim nośnikami znaczeń i symboli kształtujących opinie i postawy społeczne. Jak często podkreślają badacze, w mediach masowych, a w szczególności w serialach i telenowelach, utrwaliły się stereotypy kobiet jako strażniczek domowego ogniska, opiekuńczych matek i żon bądź bogiń seksu. Aktywność zawodowa ograniczana jest, jak wskazuje prof. Dorota Piontek,

${ }^{6}$ Potrzeby prokreacyjne oraz preferowany i realizowany model rodziny, Komunikat z badań CBOS nr BS/61/2012, Warszawa 2012.

${ }^{7}$ O. Barbuska, Czynniki determinujace udział kobiet w sprawowaniu władzy politycznej w krajach Europy Zachodniej, „Studia Europejskie” 2002, 2, s. 72-91.

${ }^{8}$ A. Giddens, Ph.W. Sutton, Socjologia. Kluczowe pojęcia, tłum. O. Siara, P. Tomanek, Warszawa 2014, s. 148-151.

${ }^{9}$ Ibidem. 
do wąskiego kręgu tradycyjnie postrzeganych zainteresowań kobiet, czyniąc je najczęściej nauczycielkami, sekretarkami czy pielęgniarkami. Stworzone w ten sposób przez media ramy poznawcze mają istotny wpływ na kształt dyskursu publicznego ${ }^{10}$.

W tym miejscu warto dodatkowo przywołać koncepcję Pierre’a Bourdieu odnoszącą się do przemocy symbolicznej. Ten typ przemocy nie oznacza realnej fizycznej siły. To sprawia, że jest łatwiej akceptowalny, a niekiedy pojmowany jako coś naturalnego ${ }^{11}$. Dzięki niemu jednostki podporządkowane odbierają rzeczywistość z tej samej perspektywy co jednostki dominujące, nie postrzegając tym samym siebie jako obiektów ucisku ${ }^{12}$. Dzięki uświadamianej im przez grupę dominującą zbieżności ich wzajemnych interesów postrzegają daną sytuację jako korzystną dla nich samych. Owa symboliczna dominacja ma miejsce na różnych polach życia społecznego. Jej autorami są także media masowe, które urosły dziś do rangi potężnego aktora, nie tylko mogącego przekazywać stereotypy, ale również je tworzyć i utrwalać. Wszystko za sprawą języka, obrazu, a także ustalania hierarchii ważności dla danych tematów i związanych z nimi postaci. Media nie są odbiciem rzeczywistości, ale same ją tworzą.

\section{Kobiety w świecie zmediatyzowanej polityki}

Pojawienie się mediów audiowizualnych wywarło wielki wpływ na współczesne społeczeństwa i sferę polityki ${ }^{13}$. Współzależność mediów i polityków nie podlega obecnie dyskusji. Jedni potrzebują ciekawych tematów - czy

${ }^{10}$ D. Piontek, Kobiety programach informacyjnych, https://wnpid.amu.edu.pl/ images/stories/pp/pp-2-2011/121-132.pdf (3.01.2017).

${ }^{11}$ P. Bourdieu, Męska dominacja, tłum. L. Kopciewicz, Warszawa 2004, s. 45$-46,50$.

${ }^{12}$ E.A. Kaniuk, Kobieta - medialna ofiara przemocy symbolicznej, [w:] Kobiety w sferze publicznej. Teoria i praktyka, red. nauk. M. Pataj, Toruń 2015, s. 97-111.

${ }^{13}$ B. Dobek-Ostrowska, Komunikowanie polityczne i publiczne, Warszawa 2012, s. $158-160$. 
nawet coraz częściej sensacji - drudzy kanału, za pomocą którego będą mogli promować swoje idee oraz utrzymywać kontakt $\mathrm{z}$ wyborcami. Profesor Bogusława Dobek-Ostrowska wskazuje w tym kontekście na zjawisko nazywane powszechnie „mediatyzacją polityki”. Polega ona na transformacji i modernizacji sfery publicznej oraz zmianach w zachowaniach uczestników komunikowania politycznego pod wpływem zarówno tradycyjnych mediów masowych, jak i nowych środków komunikowania sieciowego $^{14}$. Media masowe nie są jednak tylko biernym przekaźnikiem informacji. Jak słusznie stwierdził Marshall McLuhan - same w sobie stały się przekazem $^{15}$.

Dobrze obrazuje to słynna teoria agenda-setting, przedstawiona w 1972 roku przez Maxwella McCombsa i Donalda Shawa. Według niej media w pływają w bardzo dużym stopniu na kształtowanie się opinii publicznej, ukierunkowując uwagę widzów na pewne wydarzenia, a przy okazji ignorując pozostałe.

To ukierunkowanie uwagi rzutuje również, w mojej ocenie, nie tylko na dane wydarzenia, ale również na osoby. Fakt, że dany polityk pojawia się częściej jako komentator wydarzeń politycznych, z pewnością podnosi jego rozpoznawalność, co może mieć późniejsze przełożenie na wynik wyborczy. Badania CBOS z jesieni 2015 roku dobitnie pokazują, że głównym źródłem, z którego Polacy czerpią wiedzę o polityce, są telewizyjne programy informacyjne i publicystyczne. Wskazało na nie aż $79 \%$ ankietowanych. Ten typ audycji okazał się bardziej znaczący niż spoty i audycje wyborcze, rozmowy w gronie rodzinnym i grupach znajomych czy drukowane materiały wyborcze.

\section{${ }^{14}$ Ibidem.}

${ }^{15}$ M. McLuhan, Understanding Media. The Extensions of Man, New York 1967, s. 7. 
Wykres 1. Badanie CBOS odnośnie do źródeł czerpania wiedzy o polityce w trakcie kampanii wyborczej do parlamentu jesienią 2015 roku

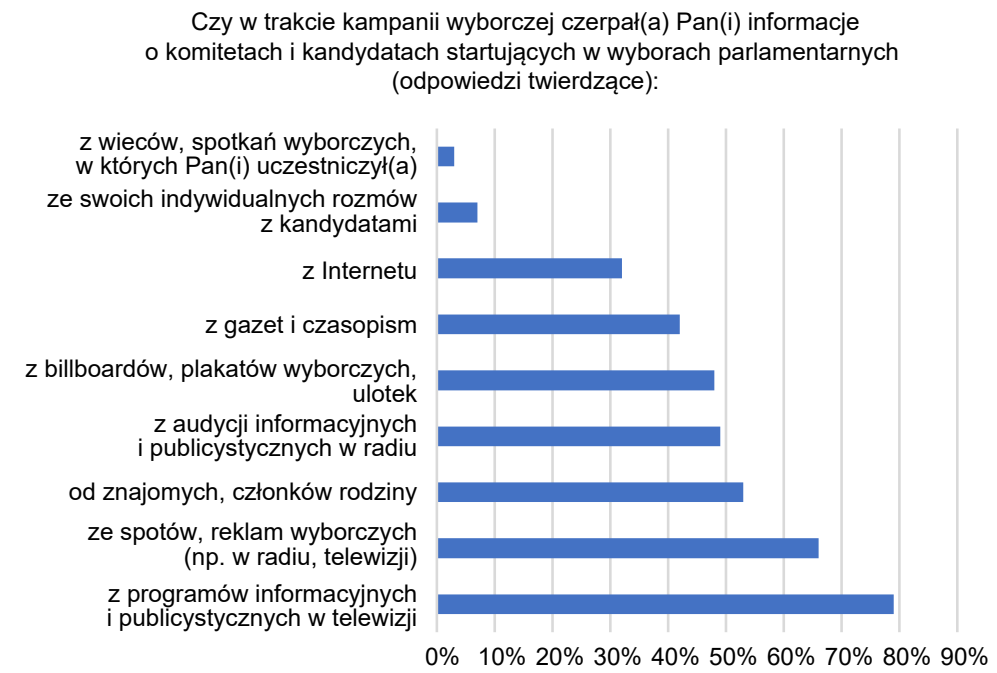

Źródło: Odbiór kampanii wyborczej i aktywność polityczna w Internecie przed wyborami parlamentarnymi, Komunikat z badania CBOS nr 164/2015, Warszawa 2015.

W nawiązaniu do zasygnalizowanych wcześniej kwestii sformułowałam hipotezę, która zakłada, że stopień obecności kobiet w programach publicystycznych głównych kanałów informacyjnych polskiej telewizji może mieć wpływ na liczbę kobiet, które angażują się w świecie polityki.

Programy publicystyczne nadawane po głównych serwisach informacyjnych cieszą się zwykle dużą oglądalnością. Ich goście mają możliwość dość szczegółowo zaprezentować swoją opinię na dany temat, a nawet przy zręcznym posługiwaniu się retoryką polityczną odwołać się do kwestii, których dziennikarz nie chciał poruszyć, a które dla polityka są znaczące. W przeciwieństwie do krótkich komentarzy polityków w serwisach informacyjnych programy publicystyczne dają rozmówcy dużo większe pole manewru, jeśli chodzi o zaprezentowanie swojego punktu widzenia. $\mathrm{Z}$ racji tego, że programy te realizowane są w zdecydowanej większości na 
żywo, polityk nie musi obawiać się, że jego wypowiedź zostanie zmontowana bądź pozbawiona najważniejszych wątków (dzieje się to oczywiście przy dalszym cytowaniu wypowiedzi w innych programach bądź mediach). $Z$ tego punktu widzenia przyjęłam również założenie, że programy publicystyczne nadawane po serwisach informacyjnych mogą mieć silne oddziaływanie opiniotwórcze i stanowią ważny element budowy wizerunku danego polityka.

Sukcesywne badania z zakresu monitoringu mediów pod względem nierówności płci prowadzi Stowarzyszenie Kongres Kobiet. W raportach opublikowanych na stronie internetowej Stowarzyszenia można znaleźć analizy obecności kobiet w telewizyjnych programach publicystycznych jak: „Fakty po Faktach”, „Kawa na Ławę”, „Tomasz Lis na żywo” oraz „Kropka nad I”. Analizy objęły cały 2015 rok. Badano w nich częstotliwość pojawienia się kobiet jako gości, kontekst rozmowy i płeć prowadzących programy. Warto jednak zwrócić uwagę, że ciężko jest porównać powyższe programy ze względu na różną częstotliwość i porę emisji oraz format rozmowy. W badaniach Stowarzyszenia Kongres Kobiet brakuje również programów stacji Polsat. Dlatego uznałam za zasadne skupienie się na programach publicystycznych, których zarówno format, jak i czas emisji są zbliżone do siebie, co umożliwia zestawienie ich ze sobą i odniesienie porównawcze.

\section{Metoda}

W badaniu została wykorzystana ilościowa analiza treści. Przedmiotem badania była liczba kobiet występujących w roli gościa w programach publicystycznych nadawanych codziennie po serwisach informacyjnych w trzech stacjach telewizyjnych: TVP Info, TVN24 i Polsat News. W przypadku TVN24 i Polsatu News analizie poddano programy „Fakty po Faktach” i „Gość Wydarzeń”. Jeśli chodzi o TVP analizie poddano program „Dziś Wieczorem”, który od 16 listopada 2016 roku nosi nową nazwę „Gość Wiadomości” - godzina i format programu pozostały bez zmian. 
Analizą objęto wszystkie audycje powyższych programów publicystycznych, które zostały wyemitowane w 2016 roku. Jednostką analizy byłjeden odcinek programu. W sumie w badaniu ujęto 358 odcinków „Faktów po Faktach”, 352 odcinki „Dziś Wieczorem”/„Gościa Wiadomości” i 604 odcinki „Gościa Wydarzeń” (jeden odcinek po wydaniu serwisu informacyjnego „Wydarzenia” o godzinie 18.50 i drugi w ramach serwisu o godzinie 22.00).

Badane programy najczęściej stanowią nawiązanie do najważniejszych wydarzeń przedstawionych w serwisie informacyjnym. Ich tematyka w zdecydowanej większości dotyczy spraw społeczno-politycznych, a gośćmi są najczęściej politycy oraz eksperci (głównie przedstawiciele świata nauki).

Za wyborem tych trzech programów przemawia fakt, że emisja po głównych wydaniach serwisów informacyjnych może sprawić, iż dotrą one do różnego rodzaju widzów - nie tylko tych, którzy przejawiają zainteresowanie polityką. Według danych portalu wirtualnemedia.pl z września 2016 roku największą popularnością wśród widzów cieszą się „Fakty po Faktach”, na drugim miejscu uplasował się program „Dziś Wieczorem”. Na trzecim miejscu znajduje się program publicystyczny również nadawany w TVP Info „Cztery Strony”, a na kolejnym „Gość Wydarzeń”. Pomimo tego, że program „Cztery strony” osiągnął lepszą oglądalność niż „Gość Wydarzeń”, ze względu na okres badania, czyli cały 2016 rok, oraz fakt, że program zaczął być emitowany od połowy marca 2016 roku, nie został on poddany analizie.

Poza badaniem częstotliwości udziału kobiet w programach publicystycznych wzięto także pod uwagę rolę, w jakiej wystąpiły rozmówczynie. W tym celu wyodrębniono następujące kategorie: polityk (niezależnie od szczebla), ekspert, przedstawicielka organizacji społecznej (w tym związki zawodowe, NGO), znana osoba (celebrytka) oraz „zwykła” osoba. Zasada przypisania do kategorii opierała się na faktycznej roli, w której rozmówczyni występuje w programie. Na przykład Magdalena Ogórek komentująca jako historyk Kościoła mszę świętą, którą papież Franciszek odprawił w ośrodku dla imigrantów, została skategoryzowana jako ekspert, a nie jako polityk, na co mogłoby wpłynąć wcześniejsze kandydowanie w wyborach prezydenckich. 
Ze względu na zróżnicowaną liczbę gości zapraszanych do jednego odcinka badanych programów („Fakty po Faktach” - średnio trzy-cztery osoby, „Dziś Wieczorem”/„Gość Wiadomości” - średnio jedna-dwie osoby, „Gość Wydarzeń" - jedna osoba) liczba kobiet, które wystąpiły w tych programach, zostanie przedstawiona w sposób procentowy.

\section{Wyniki}

W badanym okresie średnia procentowa liczba kobiet w omawianych programach publicystycznych dla całego 2016 roku kształtuje się na bardzo zbliżonym i - co warto zaznaczyć - niskim poziomie. Dla „Dziś Wieczorem”/„Gość Wiadomości” wynosi on 13,9\%, dla „Faktów po Faktach” 12,69\%, a dla „Gościa Wydarzeń” - 12,97\%. Szczegółowy rozkład procentowy na poszczególne miesiące prezentują poniższe wykresy.

Wykres 2. „Fakty po Faktach” - procentowy udział kobiet jako gości programu w 2016 roku

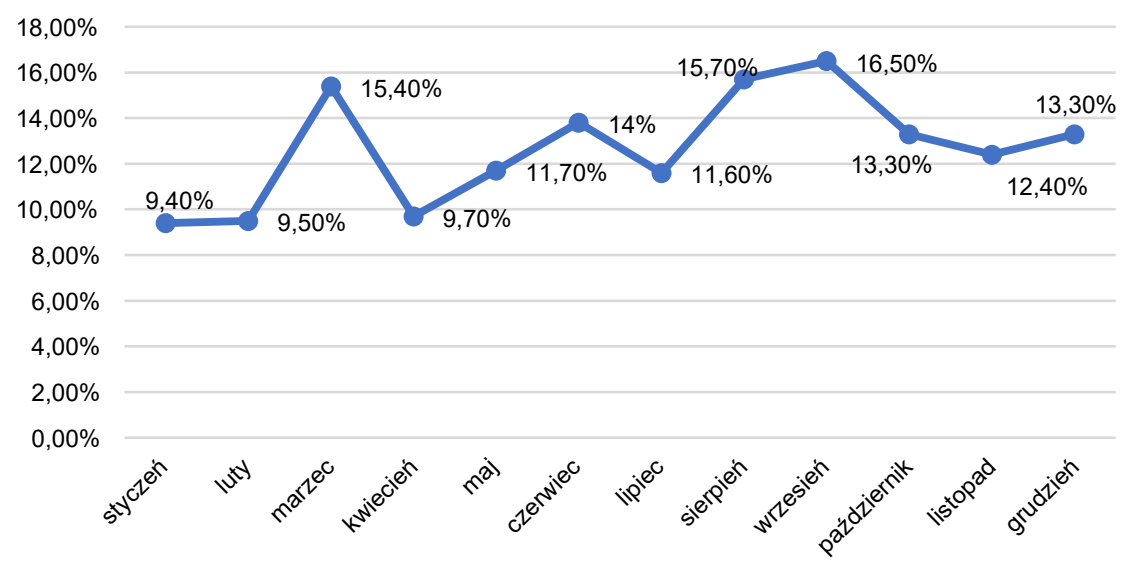

Źródło: opracowanie własne na podstawie materiałów ze strony http://faktypofaktach.tvn24.pl (10.01.2017). 
Wykres 3. „Dziś Wieczorem”/„Gość Wiadomości” - procentowy udział kobiet jako gości programu w 2016 roku

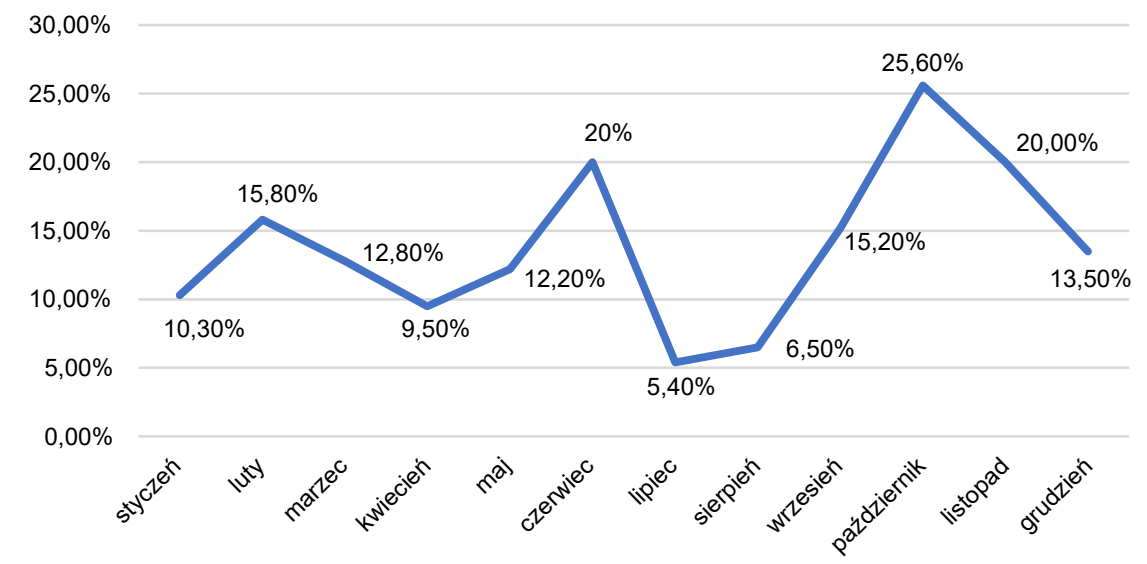

Źródło: opracowanie własne na podstawie informacji ze stron: http://www. tvp.info/14661277/dzis-wieczorem; https://vod.tvp.pl/27630329/27112016 (10.01.2017).

Wykres 4. „Gość Wydarzeń” - procentowy udział kobiet jako gości programu w 2016 roku

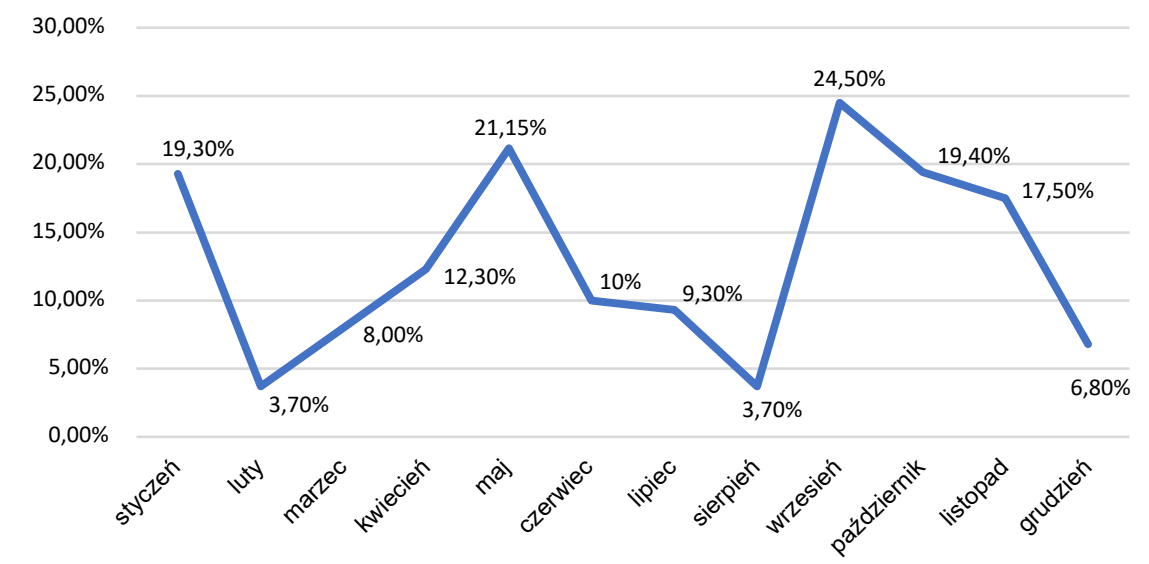

Źródło: opracowanie własne na podstawie informacji ze strony www.polsatnews.pl/program/gosc-wydarzen/ (10.01.2017). 
Jak widać na zaprezentowanych wykresach, najbardziej konsekwentny pod względem obecności kobiet w roli gościa jest program „Fakty po Faktach”. Mimo że pomiędzy kolejnymi miesiącami zachodzą niewielkie różnice w tym zakresie, to można jednak stwierdzić, że utrzymywany jest pewien stały poziom obecności kobiet, który nie jest niższy niż 9\%. W kontekście programów publicystycznych na antenach Polsatu News i TVP Info możemy zauważyć duże zróżnicowanie pomiędzy poszczególnymi miesiącami. Szczególnie wyraziste są bardzo niskie wskaźniki obecności kobiet w lipcu dla programu „Dziś Wieczorem” - tylko 5,4\% - i w sierpniu dla „Gościa Wydarzeń" - liczba kobiet spadła do dramatycznego poziomu 3,7\% (podobna sytuacja miała miejsce w lutym). Przyczyn tej sytuacji może być oczywiście wiele. Jedną z nich jest tematyka bieżących wydarzeń, która na przykład w lipcu zdominowana była przez takie tematy, jak bezpieczeństwo (zamachy terrorystyczne w Europie Zachodniej, zamach stanu w Turcji, szczyt NATO w Warszawie, Światowe Dni Młodzieży w Krakowie) czy sport (Euro 2016, igrzyska olimpijskie w Rio de Janeiro). Te tematy stereotypowo uznawane są raczej za typowo „męskie”, stąd może wynikać niska liczba komentujących je kobiet. Nie można zapominać jednak, że na wybór gościa programu wpływają również kwestie czysto techniczne - jak choćby czas i dostępność rozmówcy.

Warto również zwrócić uwagę na wspólny dla wszystkich trzech programów wzrost udziału kobiet na przełomie września i października 2016 roku. Również w tym przypadku można stwierdzić, że przyczyną jest tematyka bieżących wydarzeń, a więc projekty regulacji prawnych odnośnie do liberalizacji bądź zakazu aborcji w Polsce i związane z tym ogólnopolskie „czarne protesty” kobiet. Wszystkie programy zanotowały w tym czasie największy w przeciągu całego roku procentowy udział kobiet w swoich audycjach. Jednocześnie program „Dziś Wieczorem” ustanowił rekord dla 2016 roku, goszcząc w październiku aż 25,6\% kobiet. To pokazuje, że w świecie mediów nadal można zauważyć podział na tematy „bardziej kobiece” oraz te „bardziej męskie”.

Jak zostało zasygnalizowane wcześniej, w analizie zostały wzięte również pod uwagę role, w których wystąpiły kobiety w badanych 
programach publicystycznych. Warto zaznaczyć, że w przypadku kategorii „polityk” i „ekspert” każda ze stacji często zaprasza te same osoby, które są stałymi komentatorami bieżących wydarzeń. Jest to zjawisko niezależne od płci rozmówcy. W niniejszym badaniu ten aspekt nie został brany pod uwagę. Celem było ukazanie częstotliwości występowania kobiet w badanych programach w ogóle, bez skupiania się na różnorodności zapraszanych osób.

Szczegółowe wyniki prezentuje wykres 5.

Wykres 5. Role kobiet będących w 2016 roku gośćmi programów publicystycznych „Fakty po Faktach”, „Dziś Wieczorem”/„Gość Wiadomości” i „Gość Wydarzeń"

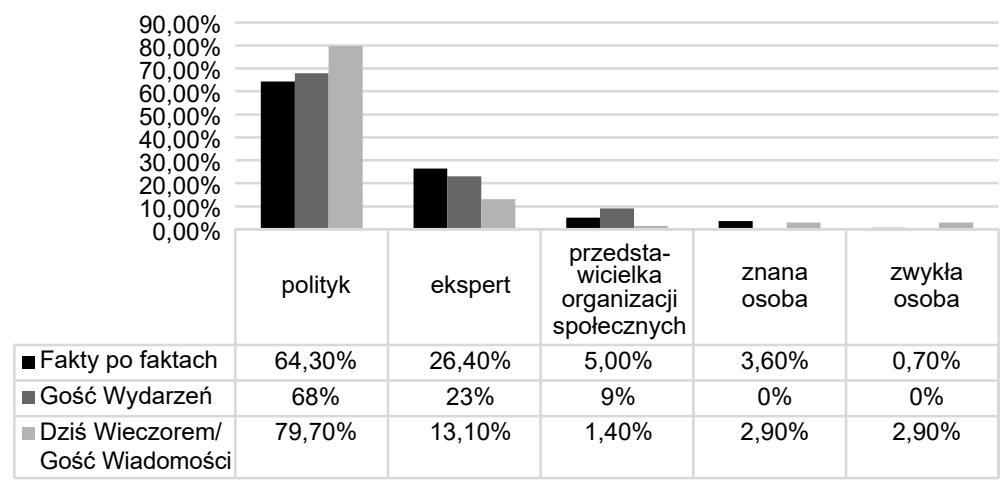

Źródło: opracowanie własne.

Na podstawie zestawienia zaprezentowanego na wykresie 5 można stwierdzić, że kobieta polityk to najbardziej popularna rola, w której występowały rozmówczynie we wszystkich trzech programach publicystycznych. Nie jest to związane typowo z płcią, a raczej z profilem tych audycji. Widać jednak wyraźną dominację programów stacji TVP Info w tym zakresie. Można tłumaczyć to faktem, że TVP jako nadawca publiczny, ściśle związany z politykami, bardzo często zaprasza do swoich programów przedstawicieli rządu czy parlamentu, aby mogli na bieżąco informować 
o swoich projektach i komentować aktualne wydarzenia. Konsekwentnie w programach stacji TVP Info - w porównaniu do TVN24 i Polsatu News - zdecydowanie mniej kobiet wystąpiło w roli ekspertów. U nadawców komercyjnych liczba kobiet odwiedzających studio w tym właśnie charakterze osiągnęła mniej więcej jedną czwartą liczby gości. Pokazuje to, że głos kobiety może być wartościową opinią, którą należy wziąć pod uwagę przy podejmowaniu także strategicznych decyzji.

Kobiety jako przedstawicielki organizacji społecznych w badanych programach pojawiały się głównie przy okazji protestów przeciw zmianom w zakresie dopuszczalności aborcji w Polsce oraz w trakcie strajku pielęgniarek w Centrum Zdrowia Dziecka w Warszawie. Jeśli chodzi o znane osoby (celebrytów), to kobiety w tej kategorii wystąpiły okazyjnie, i to zazwyczaj w roli ambasadorów konkretnych inicjatyw i wydarzeń - na przykład Maria Peszek w związku z protestami kobiet czy Maryla Rodowicz w kontekście sylwestra organizowanego przez TVP. W ostatniej kategorii „Zwykłych” osób - znalazły się przykładowo przedstawicielki rodzin ofiar katastrofy smoleńskiej.

Konkludując, powyższe wyniki badań pokazują, że udział kobiet w programach publicystycznych jest generalnie niski. W pewnych okresach mniej lub bardziej koreluje on ze stopniem zaangażowania kobiet w politykę parlamentarną (osiągając poziom powyżej 20\%). Nie jest to jednak tendencja stała, czego dowodzą niezwykle niskie wyniki dla niektórych miesięcy - na poziomie 5 i $3 \%$.

Nie da się jednoznacznie stwierdzić, która stacja jest najbardziej „prokobieca", ponieważ średnia procentowa kobiet występujących w badanych programach publicystycznych w całym 2016 roku jest mniej więcej podobna. Można jednak dokonać wyróżnienia stacji TVN24 za pewnego rodzaju systematyczność (brak widocznych drastycznych spadków udziału kobiet). Drugą pozycję w tym zakresie zajmuje TVP Info, które tylko w lipcu i sierpniu zanotowało znaczący spadek poniżej 10\%. Najgorzej pod względem systematyczności wypada Polsat News - w przypadku tej stacji w ciągu aż pięciu miesięcy udział kobiet spadł poniżej 10\%, dwa razy osiągając niezwykle niski poziom 3,7\%. 
W zakresie różnorodności ról kobiet, które wzięły udział w badanych programach, również najlepiej wypadł program stacji TVN24. Na szczególną uwagę w „Faktach po Faktach” zasługuje wysoki wskaźnik kobiet występujących w roli ekspertów (tu również wysoki wynik należy do Polsatu News).

\section{Podsumowanie}

Rozpoznawalność jest dziś jednym z kluczowych czynników, który pozwala zaistnieć w świecie polityki. Ciekawy komentarz do bieżącej sytuacji może bardziej przekonać wyborców niż ulotka czy plakat wyborczy. Obecność w programie publicystycznym jest sygnałem, że dana osoba może mieć coś szczególnego do powiedzenia - w końcu została wybrana przez gospodarza programu - a jej komentarz powinien zostać wzięty pod uwagę. W ten sposób media, a w szczególności telewizja, ze względu na siłę oddziaływania zarówno obrazem, jak i dźwiękiem mają ogromny wpływ na społeczną świadomość.

W tym kontekście relatywnie niska obecność kobiet w programach publicystycznych o tematyce społeczno-politycznej może utrwalać społeczny stereotyp o tym, że polityka jest głównie domeną mężczyzn. Co więcej, również w programach informacyjnych - co pokazała w swoich badaniach prof. Dorota Piontek - mamy do czynienia ze stereotypizacją, która wiąże się z przypisywaniem kobiet do konkretnych ról i tematów ${ }^{16}$.

Warto więc, aby w parze ze zmianami prawnymi na rzecz zwiększania udziału kobiet w polityce szły również przemiany w świadomości społecznej. Tak, aby aktywność kobiet w sferze publicznej nie była faktem wymuszonym, ale skutkiem realnego i niczym nieskrępowanego zaangażowania. Kwoty wyborcze odgrywają ważną rolę, ale tylko w momencie samego wyboru na stanowisko. Późniejszy etap, tj. formułowanie projektów, udział w podejmowaniu decyzji, przedstawianie swojego punktu widzenia

${ }^{16}$ D. Piontek, op. cit. 
odnośnie do realizacji konkretnej strategii politycznej, ma jeszcze większe znaczenie. Warto więc postawić pytanie, czy głównym celem powinno być tylko samo zwiększenie wybieralności kobiet na stanowiska polityczne, czy też doprowadzenie do ich faktycznego, a nie tylko fasadowego udziału w sprawowaniu władzy polegającego między innymi na stanowieniu „ładnego tła" na konferencji prasowej. Ta przemiana jest o wiele trudniejsza do przeprowadzenia, ponieważ wiąże się ze zmianą mentalności. Nie da się jej wprowadzić przy pomocy regulacji prawnych. Dlatego tak ważne jest czynne zaangażowanie się $\mathrm{w}$ ten proces instytucji biorących udział $\mathrm{w}$ procesie socjalizacji, w szczególności socjalizacji politycznej.

Media mają w tym aspekcie kluczowe znaczenie. Pokazując kobiety jako aktywne komentatorki życia publicznego i ekspertki w swoich dziedzinach, mogą zasadniczo wpłynąć na zmianę świadomości zarówno mężczyzn, jak i samych kobiet. Mężczyźni dostrzegą w kobietach wartościowego partnera do dyskusji, a kobiety uwierzą, że ich zaangażowanie nie kończy się na tradycyjnie przypisywanej im sferze prywatnej. Dzięki temu równość płci w polityce i w ogóle w sferze publicznej będzie nie tyle prawną regulacją, ile normalną praktyką w demokratycznym społeczeństwie. 